\title{
Caligrafias da existência: narrativas de Moçambique em Mia Couto
}

\author{
Cristina Maria da Silva*
}

\begin{abstract}
Resumo
Propomos pensar os encontros entre escrita e oralidade através das obras Terra Sonâmbula e Um rio chamado tempo, uma casa chamada terra do escritor Mia Couto. A terra e o rio são metáforas da recordação, falas e suportes da existência. Neles se inscrevem caligrafias da existência, nas quais os espaços da recordação, conforme define Assmann, aparecem inscritos nas tramas dos personagens. Esses se desvelam como metáforas, que se dão na escrita como vestígio da cultura, na imagem (sobretudo as fotografias, as lembranças e os sonhos), nas escritas do corpo e na memória dos lugares. Mia Couto inscreve em sua literatura narrativas sobre Moçambique. Sua literatura se avizinha da oralidade e percorre o chão da cozinha, de onde ouve histórias contadas aos sussurros, em um mundo doce e mágico, no qual convivem vivos e mortos, caminhantes e sobreviventes. Nas letras dos sonhos inscritas nos Cadernos de Kindzu, nas cartas lidas por Mariano, encontramos as "páginas da terra", que têm sotaques que pedem para serem ouvidos. Os corpos se estendem aos artefatos, como a casa, os álbuns de fotografias, e nos cadernos e nos sonhos se inscrevem as práticas de escrita das relações e, por assim dizer, da própria memória.
\end{abstract}

Palavras-chave: Espaços da recordação. Narrativas. Memória. Literatura moçambicana.

\section{Calligraphies of existence: Narratives of Mozambique in Mia Couto's literature}

\begin{abstract}
We propose to consider the encounters between writing and orality in the books Sleepwalking Land and A river called time, by Mia Couto. The land and the river are metaphors of remembrance, speeches and supports of existence. They have been inscribed with the calligraphy of the existence, in which the spaces of remembrance, as defined by Assmann, are inscribed in the plots of the characters. These are revealed as metaphors, which are given in writing as a vestige of culture, in the image (especially photographs, memories and dreams), in the writings about the body and in the memory of places. Mia Couto performs these inscriptions through his narrative literature about Mozambique. His literature is close to orality as he walks on the kitchen floor, where he hears stories told in whispers, in a sweet and magical world in which the living and the dead, walkers and survivors live together. In the words of the dreams inscribed in the Notebooks of Kindzu, in the letters read by Mariano, we find the "pages of the land": they have accents that ask to be heard. Bodies have their existence poured into artifacts, such as the house, photo albums, in the notebooks and dreams, in which the practices of the writing of relationships and of memory itself are inscribed.
\end{abstract}

Keywords: Spaces of Remembrance. Narratives. Memory. Mozambican Literature.

Recebido: 27/01/2019

Aceito: 07/04/2019

* Universidade Federal do Ceará (UFC). Professora Associada do Departamento de Ciências Sociais. 


\section{Introdução: as lembranças da língua}

Já não necessito de lhe escrever por caligrafia palavra. [...] Há um rio que nasce dentro de nós, corre por dentro da casa e desagua não no mar, mas na terra. Esse rio uns chamam de vida. (COUTO, 2003, p. 258)

Mia Couto se coloca como um "escutador" da sua cultura. Nos seus escritos somos levados por uma poética de enfrentamento diante do existir. ${ }^{1}$ Com as metáforas Rio e Terra nos conduz a pensar nas correntezas da vida, no que faz voar e na fluidez dos encantamentos e sonhos e no que nos prende e nos faz sedentários, o que nos faz também raízes. A Terra é sonâmbula, os territórios não são palpáveis, são de solo incerto, dela sai uma escrita que aspira "sotaques do chão" (COUTO, 2005, p. 224). Terra e rio falam. Enunciam o que somos e as relações que nos tecem.

Nas obras Terra Sonâmbula (primeiro romance publicado de Mia Couto em 1992) e em Um rio chamado tempo, uma casa chamada terra (publicado em 2002), propomos pensar sobre as caligrafias da existência. Como esses dois livros tecem Moçambique, um território de oralidades, no cenário da prática escrita? Como traduzir uma cultura, que espaços da recordação acionar para que os rastros da existência oral apareçam?

Terra (do latim tellus) quer dizer território árido ou lugar seco, o que se opõe ao mar. Rio (do latim rivus) quer dizer fluxo. Nas definições mais antigas se diz que o rio era o elemento principal para se estabelecer um domicílio. Nas duas obras de Mia Couto, terra e rio se encontram. É preciso que eles se encontrem para que o habitar humano seja possível. O caminhar dos fluxos dos rios deixa amolecer o solo seco para que a morada humana, por meio da casa, exista. O rio é fluxo; a terra é o corpo, é ter onde repousar; e a casa, como lócus, é a possibilidade de se ter raiz. "Quem constrói a casa não é quem a ergueu mas quem nela mora." Sem residentes, até mesmo as casas de cimento apodreciam, lembra Kindzu (COUTO, 2007, p. 23).

Em uma das cartas do avô Mariano, ele indaga:

A terra pode amolecer por força do amor? Só se o amor for uma chuva que nos molha a alma por dentro. [...] Esta terra começou a morrer no momento em que começámos a querer ser outros, de outra existência, de outro lugar: Luar-do-Chão morreu quando os que a governam deixaram de a amar. Mas a terra não morre, nem o rio se suspende. (COUTO, 2003, p. 195).

$\mathrm{Na}$ obra de Mia Couto estão presentes os embates e os limites entre a língua do colonizador, o português, as diversidades linguísticas em Moçambique e mesmo de gênero. Ele, filho de portugueses, branco de olhos claros, com um codinome feminino. Em 2011, por exemplo, no congresso luso-afrobrasileiro de ciências sociais, foi questionado sobre como podia ele estar ali falando de literatura africana sendo um branco. Sua resposta, não menos política do que a pergunta, assinalou: "Não estou aqui como um branco, ou o que quer que seja, estou aqui como moçambicano, como um escritor, e como escritor eu posso ser o que eu quiser. Posso ser uma mulher, um bicho, uma planta." Essa resposta é interessante porque lembra um pouco um dos textos que citarei posteriormente; mas também porque há o indício de certa tensão entre o que ele escreve, seu lugar como descendente de portugueses e as relações dentro de seu país com outros africanos, sobretudo, com os negros. Sobre o texto, ao qual me refiro, ele intitula o subtítulo como "minha pátria é a minha língua portuguesa." Segue: 
Na minha infância acreditava ser gato. Eu não pensava eu era um gato. Para testemunho deste delito de identidade, meus pais guardam provas documentais: fotos minhas comendo e dormindo entre os bichos. Fui ensinado a afastar-me do gato que desejava tomar posse de mim. Depois me inventei outros bichos. Um pequeno leopardo que tivemos uns dias no nosso quintal me fez ser felino. Perante ele, o meu ser humano era pouco, imperfeito, carente. [...] Ser humano foi talvez o que nunca aspirei. Ao fim de muita insistência lá me resignei. Mas, ao menos fosse bombeiro. Cedo aprendemos o mundo como uma casa ameaçada de incêndio. [...] Mas estava escrito: eu havia de ser homem. Educaram-me. Isto é, fui aprendendo a ter medo de querer ser outra coisa. Encontrei refúgio nas pequenas estórias. Sonhar, sonhar-me, esquecer-me, vencer-me sem ter que lutar contra nada. Através do sonho que já havia viajado de identidade: já fora bicho, bombeiro, e até pessoa. Sem saber eu já estava escritor, portador assintomático dessa doença chamada poesia. (COUTO, 2011, p. 184-185).

Mia Couto inscreve, em sua literatura, Moçambique e, por sua vez, uma África que nos é familiar, que vive em nós, talvez não mais na via da representação, mas do narrar o que vê e o que sente, como se fosse um tradutor de sonhos. Sua literatura se avizinha da oralidade, uma escrita que aspira acompanhar seus movimentos. Percorre o chão da cozinha, de onde ouve e recolhe histórias contadas aos sussurros, um mundo mágico que entrelaça a vida do escritor em sua biografia, como, por exemplo, com a biografia de seu personagem Mariano, tanto o neto como o avô. ${ }^{3}$

Todavia, o que a língua teria a ver com suas lembranças? Mia Couto explica que, para manter "residência na infância" (COUTO, 2011, p. 185), necessita de uma língua em estado de infância. Sendo assim, a seu favor, teve em Moçambique um lugar em estado de infância, e foi nascendo junto com ela. Ele e sua terra são da mesma geração. Esse trânsito entre línguas pode ser visto quando Kindzu pensa nas suas semelhanças com Farida, em Terra Sonâmbula: "Nós dois estávamos divididos entre dois mundos. A nossa memória se povoava de fantasmas da nossa aldeia. Esses fantasmas nos falavam em nossas línguas indígenas. Mas nós já só sabíamos sonhar em português. E já não havia aldeias no desenho do nosso futuro." (COUTO, 2007, p. 92).

No romance, a língua portuguesa é onde escritor e personagens estão a inventar uma pátria para si. Ela é também o solo onde se constrói uma Moçambique em palavras. Assim:

A escrita é uma casa que eu visito, mas onde não quero morar. O que me instiga são as outras línguas e linguagens, sabedorias que ganhamos apenas se de nós mesmos nos soubermos apagar. Da minha língua materna eu aspiro esse momento em que ela se desidioma, convertendo-se num corpo sem mando de estrutura ou de regra. O que quero é esse desmaio gramatical, em que o português perde todos os sentidos. Nesse momento de caos e perda, a língua é permeável a outras razões, deixa-se mestiçar-se e torna-se mais fecunda. A língua é, só então, viagem viajada, namoradeira de outras vozes e outros tempos. (COUTO, 2011, p. 186).

Nessa costura, o tempo é outro, não é linear ou cronológico, é antes circular. Nele a escrita acompanha os sons da terra, os movimentos das nuvens, das árvores e do céu e a escuta dos mortos. Em suas palavras, o tempo tem uma filosofia própria do mundo rural africano:

O tempo é entendido como uma entidade circular. Nesse universo apenas o presente é credenciado. A ideia de um tempo redondo não é uma categoria exclusivamente africana, mas de todas as sociedades que vivem sob o domínio da lógica da oralidade. Foi a escrita

3 Mia Couto é fascinado por gatos. O avô Mariano possuía um gato treinado para os indevidos fins de encontrar moça solteira, disposta e disponível; foi assim que ele encontrou Dulcineusa (Cf. COUTO, 2011, p. 48). Além disso, se o chão da cozinha de casa era o lugar privilegiado do escritor para ouvir as histórias de infância, Em um rio chamado tempo, uma casa chamada Terra, também Mariano, o neto, encontra na cozinha o lugar onde se transporta para distantes doçuras (Cf. COUTO, 2011, p. 145). Não teria alguma proximidade também nas biografias o fato de que em NyumbaKaya, em Luar-do-Chão, a cozinha ser como no modo europeu? "cozinhando dentro, comendo fechados" e não fora ou nos quintais." (Cf. COUTO, 2011, p. 145). 
que introduziu a ideia de um tempo linear, fluído e irreversível como a corrente de um rio. Nos casos de Angola e Moçambique, contudo, a lógica da escrita é ainda um universo restrito. Politicamente hegemônico, mas dominado do ponto de vista da representação que fazemos do mundo. Para a oralidade, só existe o que se traduz em presença. Só é real aquele com quem podemos falar. Os próprios mortos não se convertem em passado, porque eles estão disponíveis a, quando convocados, se tornarem presente. Em África, os mortos não morrem. Basta uma evocação e eles emergem para o presente, que é o tempo dos viventes. (COUTO, 2011, p. 123-124).

Para Mia Couto não é o escritor que importa, mas a obra que está a fazer. Ele existe para ouvir os outros. Aliás, melhor dizendo, "Todo escritor é um escutador" (COUTO 2017). Para ele foi no chão da cozinha que sua literatura nasceu. Um mundo doce que o cercava: "Eu me sentava para fazer os deveres de casa e ali naquele universo ouvia histórias...contadas aos sussurros, o que me fascinava" (COUTO 2017). Contudo, em suas palavras, não é o escritor quem importa, mas a obra que ele está a fazer. Só se toma o escritor a sério no momento da escrita. "Antes e depois ele está ali para ouvir os outros." (COUTO 2017).

As tensões entre seu pertencimento luso e seu nascimento em África perpassam sua fisionomia e seu pertencimento ao mundo do colonizador português. Mas, sendo nascido em Beira, e em África sendo, portanto, africano, isso promove erosões num pensamento reducionista para analisar sua obra e o impacto de seus escritos. Perguntas ligeiras e simples não dão conta da complexidade de seus pertencimentos. Mais do que epistemologias, são arqueologias do saber de África e sobre África que entram em cena.

Eu não me considero representante de Moçambique, me considero apenas representante de mim mesmo. Eu tenho duas dificuldades: eu sou de um continente em que os brancos são minorias. Os brancos moçambicanos são minoria. Num país de 21 milhões, os brancos são 10 ou 20 mil. Portanto, eu não poderia ser o representante de qualquer coisa, se é que existe isso de representatividade. E outra dificuldade é que eu tenho nome de mulher. Agora já não acontece tanto, mas antes, quando eu ia visitar um outro país, muitas vezes estavam esperando uma mulher negra. E eu ficava no aeroporto esperando que alguém viesse falar comigo e nada. (COUTO, 2011).

Ele não entende que tenha como missão representar Moçambique, não toma para si essa responsabilidade de criar uma literatura moçambicana, talvez porque entenda os limites da representação e seus muitos pertencimentos, como homem e como escritor. Mas diz não criar literatura para "inscrever qualquer coisa". Em suas palavras: "Beira tinha 50 mil habitantes quando nasci... foi feita por engano, era para ser numa margem e feita na outra... é uma água natal. Um lugar que tava ali por engano, isso me ajudou a viajar..." (COUTO, 2017).

Do que sua literatura nos fala? Primeiro, da língua, esse primeiro sussurro que nos inscreve no mundo e nos obriga a dizer, se relembrarmos, as palavras de Roland Barthes (1977), mas traduz um mundo de oralidades nas caligrafias da escrita. Experimenta trazer em sua tessitura suas vozes e seus ruídos. Mia Couto é escritor e biólogo. As duas áreas se entrelaçam em seu ofício, como se escutasse uma fúria selvagem no humano e, nas criaturas selvagens, uma linguagem. Como ele mesmo afirma: "A biologia me interessa como uma linguagem. Como se eu fosse um tradutor do que a floresta tem a me dizer." (COUTO, 2015, tradução nossa). ${ }^{4}$ Nessa mesma entrevista, ao falar, por exemplo, de A Confissão da Leoa, afirma que o livro fala de uma mulher que se transforma em leoa. Talvez, para

4 Entretien par Marine Landrot: Mia Couto veut "respecter l'oralité, tout en la recréant pour en faire de la littérature. "La biologie m'intéresse comme un langage. Comme si j'étais traducteur de ce que la forêt a à me dire”. Mais adiante, sobre o livro A Confissão da Leoa afirma: "Par exemple, mon dernier livre parle d'une femme qui se transforme en lionne. Pour vous, c'est quelque chose d'extraordinaire, alors que pour une personne du Mozambique, c'est tout à fait normal, cela fait partie de l'imaginaire quotidien." 
nós isso poderia ser uma coisa extraordinária, o que, por sua vez, para uma pessoa de Moçambique é algo normal, faz parte do imaginário cotidiano. Sua obra amplia a noção do que temos sobre o humano e sua relação com o meio, qual a pobreza que impregna a nossa humanidade e como somos pessoas como um todo, nas relações que tecemos e nos artefatos que nos rodeiam, como a casa, nossos álbuns de fotografias, nossos corpos e lembranças. Em suas palavras: "A ideia do "meio ambiente" pressupõe que nós, humanos, estamos no centro e as coisas moram à nossa volta. Na realidade, as coisas não nos rodeiam, nós formamos com elas um mesmo mundo, somos coisas e gente habitando um indivisível corpo" (COUTO, 2011, p. 21).

Percorrendo a savana, Mia Couto afirma encontrar pessoas que não sabem ler livros, mas sabem ler os sinais da terra, das árvores, dos bichos, das nuvens, sabem falar com os mortos e com os antepassados; certamente é com essas pessoas que o escritor precisa aprender a ler a vida, e a escrita dos outros: sejam pessoas, cidades, eventos, natureza, a vida que se deixa ler e da qual podemos reconstituir experiências e narrativas. Escrever é como uma costura:

A terra, a árvore, o céu: é na margem desses mundos que tento a ilusão de uma costura. É uma escrita que aspira ganhar sotaques do chão, fazer-se seiva vegetal e, de quando em quando, sonhar o voo da asa rubra. É uma resposta pouca perante os fazedores de guerra e construtores de miséria. Mas é aquela que sei e posso, aquela em que apostei a minha vida e o meu tempo de viver. (COUTO, 2005, p. 225).

Em Aleida Assmann, a escrita é apresentada como uma das metáforas do lembrar, junto com a imagem, o corpo e os lugares. O que se inclui ou não no universo da escrita? Quais as relações e tensões entre o mundo escrito e o não escrito? Quais suas interações com os universos culturais aos que se vinculam?

A escrita foi por muito tempo visto como um "rastro privilegiado" que os humanos deixam de si mesmos. Uma arma contra o esquecimento. Escrita e rastros foram usados, muitas vezes, como sinônimos, pois parecia ser essa a prática mais duradoura para que os humanos deixassem inscritos seus trajetos, sobrevivessem para além de seu tempo e transmitissem sua mensagem. Contudo, no século XVIII e XIX, essa noção de "rastro duradouro" passa a ser abalada, já não se têm garantias de que sejam tão duradouros, desconfia-se dessa força conservadora dos textos e de que sejam um nexo seguro entre o passado, o presente e o futuro, trabalho feito, sobretudo, pelos historiadores que põem em dúvida a confiabilidade da escrita (ASSMANN, 2011, p. 223).

O texto passa a ser um lugar de decifração, pois, como lembra Gagnebin, lendo Assmann, "rastros não são criados, - como são outros signos culturais e linguísticos -, mas sim deixados ou esquecidos." Não está claro e dado o que o texto entrega como mensagem. Assim sendo: "As fontes escritas não são mais consideradas documentos integrais e confiáveis, mas sim documentos aleatórios, fragmentos de um passado desconhecido, farrapos de um tecido que se rasgou." (GAGNEBIN, 2006, p. 112113). Nas palavras de Gagnebin, a palavra sèma tem na sua origem a definição de túmulo e só depois de signo, pois "o túmulo é o signo dos mortos; túmulo, signo, palavra, escrita, todos lutam contra o esquecimento." (GAGNEBIN, 2006, p. 112). Talvez por isso, seja nas cartas de um morto que Um rio chamado tempo, uma casa chamada terra se constrói.

Me faça um favor: meta no meu túmulo as cartas que escrevi, deposita-as sobre o meu corpo. Faz conta me ocuparei em ler nessa minha nova casa. Vou ler a si, não a mim. Afinal, tudo o que escrevi foi por segunda mão. A sua mão, a sua letra, me deu voz. Não foi senão você que redigiu estes manuscritos. E não fui eu que ditei sozinho. Foi a voz da terra, o sotaque do rio. (COUTO, 2003, p. 238).

A escrita passa a se apresentar como um rastro a ser decifrado, no qual encontramos vestígios da cultura e do que não foi escrito, sobretudo, quando pensamos na literatura africana e seus 
pertencimentos e elos com culturas orais. A escrita construiu um modo de ler o mundo, um outro tempo. Um mundo contínuo, linear. Essa cultura escrita invade o espaço e capitaliza o tempo, pela dinâmica do olho, que a tudo perscruta e a tudo classifica de maneira enciclopédica (CERTEAU, 2011) e se opõe à dinâmica da palavra, que tem corpo, cheiro e, portanto, respira e traz os ruídos do vivido. Além disso, é também uma prática restrita, do ponto de vista social, a determinados grupos letrados o seu acesso, se pensarmos em África e mesmo entre nós. Como pensarmos a inscrição desse mundo oral que se inscreve na escrita? Mia Couto parece traduzir ao mesmo tempo que cria uma nova língua. Trapacear a língua com a própria língua, como intuiu Barthes (1977)? Mia Couto lembra em uma entrevista:

Um dia eu estava chegando em casa e já estava escuro, já eram uma seis da tarde. Havia um menino sentado à minha espera. Quando cheguei, ele se apresentou, mas estava com uma mão atrás das costas. Eu senti medo e a primeira coisa que pensei é que aquele menino ia me assaltar. Pareceu quase cruel pensar que no mundo que vivemos hoje nós podemos ter medo de uma criança de dez anos, que era a idade daquele menino. Então, ele mostrou o que estava escondendo. Era um livro, um livro meu. Ele mostrou o livro e disse: "Eu vim aqui devolver uma coisa que você deve ter perdido." Então, ele explicou a história. Disse que estava no átrio de uma escola, onde vendia amendoins, e de repente viu uma estudante entrando na escola com esse livro. Na capa do livro, havia uma foto minha e ele me reconheceu. Então pensou: "Essa moça roubou o livro daquele fulano". Porque como eu apareço na televisão, as pessoas me conhecem. Então ele perguntou: esse livro que você tem não é do Mia Couto?" E ela respondeu: "Sim, é do Mia Couto." Então, ele pegou o livro da menina e fugiu. (COUTO, 2017).

O escritor retoma essa história para narrar como é recente a relação dos moçambicanos com os livros e ainda é distante a relação entre os escritores e os leitores. A associação de escritores faz encontros em escolas primárias e secundárias, em fábricas, mas, além disso, existe o problema do custo caro dos livros. Diante disso, podemos pensar como nas duas ficções, aqui abordadas, Moçambique e suas narrativas aparecem recorrendo às muitas linguagens que perpassam seu cotidiano. Uma maneira de mostrar que as páginas da vida se inscrevem de muitas formas?

\section{Metáforas da recordação: a terra, a casa e o corpo}

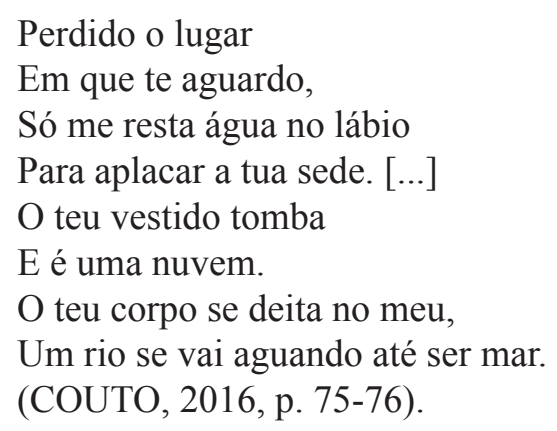

Em Terra Sonâmbula, conhecemos a terra pelas letras escritas nos Cadernos de Kindzu, seguimos as leituras e os passos de Muidinga e do velho Tuahir. Duas histórias cruzam-se numa só narração para falar das guerras civis de Moçambique. Eles vagam entre os escombros da guerra, entre as paisagens inundadas de tristezas. Avançam descalços tocando a terra, "suas vestes têm a cor do caminho.", a estrada que eles encontram "está mais deitada que os séculos, suportando sozinha toda a distância. Pelas bermas apodrecem carros incendiados, restos de pilhagens. Na savana em volta, apenas os embondeiros contemplam o mundo a desflorir." (COUTO, 2007, p. 9).

Enquanto faminto, o velho Tuahir busca para o corpo a comida. Muidinga vasculha o autocarro 
que encontram e nele encontra os doze cadernos de Kindzu para alimentar sua alma. Decifra as letras e ao ler era coisa que se recordava saber. Muidinga é quem lê os cadernos. Lê para si e em voz alta para o velho. O que sabemos, sobre essa história, é o que nos traduzem os seus olhos. ${ }^{5}$

O nome de Kindzu se confunde com a natureza, corpo e terra se metamorfoseiam. Seu nome é o mesmo que se dá "as palmeiras mindinhas, essas que se curvam junto às praias." (COUTO, 2007, p. 15). Ele cresceu entre narrativas do pai, elas faziam o lugar onde viviam maior do que mundo. A mãe ensinava os filhos a serem sombras, "sem nenhuma outra esperança senão que os muitos filhos seguissem do corpo para a terra. Do pai ele herda a narração, que se dá pela escrita e pela caminhada. O pai "sofria de sonhos" (COUTO, 2007, p. 16).

[...] nenhuma narração tinha fim, o sono lhe apagava a boca antes do desfecho. Éramos nós que recolhíamos seu corpo dominhoso. Não lhe deitávamos dentro da casa: ele sempre recusara cama feita. Seu conceito era que a morte nos apanha deitados sobre a moleza de uma esteira. Leito dele era o puro chão, lugar onde a chuva também gosta de deitar. Nós simplesmente lhe encostávamos na parede de casa. Ali ficava até de manhã. (COUTO, 2007, p. 16).

Enquanto os pés do jovem e do velho tocam a terra, são os mortos os narradores. As letras de Kindzu perscrutam a terra e as vidas dos que ali vivem e passam. Ele próprio seguia como um pássaro "atravessando os poentes." (COUTO, 2007, p. 32). Mortos e vivos transitam em indivisíveis mundos. A própria Moçambique é nessa "geografia narrativa" viajante e andarilha, pois através dos sonhos que ela e os seus se buscam.

Em Um rio chamado tempo, uma casa chamada terra, vemos como se compõem caligrafias da existência. A casa é corpo, o corpo é a terra e a terra é a mulher. Talvez por isso, um dos primeiros conselhos do avô Mariano seja:

Fazer amor, sim e sempre. Dormir com mulher, isso é que nunca. Dormir com alguém é a intimidade maior: Não é fazer amor. Dormir, isso que é íntimo. Um homem dorme nos braços de uma mulher e a sua alma se transfere de vez. Nunca mais ele encontra suas interioridades. Por isso, de noite, puxava a esteira para fora do quarto e deitava na sala." (COUTO, 2003, p. 46).

É um mundo feminino que alicerça a casa, que inunda a cozinha e tece o tempo da vida. O corpo da casa só é desvelado quando morre o velho Mariano. A casa passa a levantar voo como se fosse nuvem. Cabe à avó procurar as chaves e entregá-las ao neto, elas abririam os caminhos dos segredos sobre sua vida, para descobrir a mulher que realmente gerara sua vida, a mulher em quem realmente seu avô se permitiu dormir ou ser amado. ${ }^{6}$

A avó Dulcineusa é quem conhece o caminho das águas, ela é quem rega a casa todos os dias. "Todos os dias a avó regava a casa como se faz a uma planta. Tudo querer ser aguado, dizia ela. A casa, a estrada, a árvore. E até o rio deve ser regado." (COUTO, 2003, p. 31). "O rio é o tempo." (COUTO, 2003, p. 61). O Avô seria a terra por isso não parece ter sido de muitas palavras enquanto vivo, nem entregue aos sonhos, e era também receoso com os braços de mulher e de se perder em intimidades.

Todavia também se tornam extensões do corpo as cartas escritas entre vivos e mortos, e também

5 Cf. Alberto Manguel em seu texto "Última Página", em Uma História da Leitura, nos faz pensar que ler as letras de uma página é apenas um dos disfarces dos leitores, podemos encontrá-los nos astrônomos, no arquiteto, no zoólogo, na dançarina, no coreógrafo, no público, que lê uma dançarina dançar. No tecelão, nos pais adivinhando os rostos de seus bebês, nos adivinhos, nos amantes que leem os corpos dos seus amados à noite, no psiquiatra, nos pescadores, nos agricultores. Todos compartilham com os leitores de livros a arte de decifrar e traduzir signos.” (MANGUEL, 1997, p. 19).

6 Um belo filme que dialoga com essa passagem é Our souls at night de 2017, do Diretor Ritesh Batra. Traduzido em português como Nossas Noites. 
os álbuns fotográficos que revelam as existências de seus habitantes. Na trama do romance, o tempo delineia-se entre esses fragmentos, nos quais passado e presente se misturam, do futuro nada se sabe. A casa é personagem vivo que compõe o enredo, ela não é apenas cenário, torna possível as relações. Seu chão é onde os passos se tornam possíveis, onde as conversas acontecem, onde os corpos se aproximam e se aquecem procurando amor. Em O Último Voo do Flamingo também encontramos que é a terra que guarda nossas raízes, mas é a mulher que é a raiz da terra. "O chão é um papel, tudo se escreve nele." (COUTO, 2005, p. 186). Tanto no corpo como no chão tudo se escreve. ${ }^{7}$

Mariano retorna à casa familiar, entra, visita seus cômodos, as fechaduras e as chaves nem se reconhecem mais. Ele volta pela morte do avô, também chamado Mariano. Duas pontas da vida que se encontram, duas gerações. Nas palavras do avô, quando o neto nasceu ele o chamava de água. Quando ele morre e se despede, em uma de suas cartas, o chama de água outra vez, pois ele é quem o prossegue, "Mesmo antes de ter nome de gente, essa foi a primeira palavra que lhe dei: madzi. E agora lhe chamo outra vez de "água". Sim, você é a água que me prossegue, onda sucedida em onda, na corrente do viver.” (COUTO, 2003, p. 238).

A avó anda com chaves que já não encontram portas a serem abertas, se existem, já não sabe onde estão. Mariano tenta descobri-las:

Vou pelo corredor, alma enroscada como se a casa fosse um ventre e eu retornasse à primeira interioridade. O molho de chaves que a Avó me dera retilinta em minha mão. Já me haviam dito: aquelas chaves não valiam de nada. Eram de fechaduras antigas, há muito mudadas. Mas a avó Dulcineusa guardava-as todas, porque sofria de uma crença: mesmo não havendo porta, as chaves impediam que os maus espíritos entrassem dentro de nós. Agora, afirmo: nenhuma chave se ajusta em nenhuma fechadura. (COUTO, 2003, p. 111).

As pessoas e o seu ambiente social estão nos alicerces da casa, ela é artefato e extensão de suas realizações, de seus desesperos e desejos. A construção rememora tudo o que somos. Como diz o avô Mariano: "o importante não é a casa onde moramos. Mas onde, em nós, a casa mora." (COUTO, 2003, p. 54). Quais as casas que, ao fecharmos os olhos, vemos? Mesmo as que não existem não vivem nítidas em nós, com seus cômodos ocupados, seus cheiros, passos e rangeres de portas?

O tempo e a casa aproximam pessoas, gestos, lembranças. As mulheres arquitetam a casa no romance, elas são a casa. Encarnam nas peles das suas paredes ou no chão úmido a vida que habita os que nela vivem ou passaram. A casa é habitação dos vivos, mas também dos mortos que nela rodeiam e sussurram desejos, rancores, arrependimentos e sonhos. Abrigo dos viventes e das divindades, lugar onde se ouvem os sussurros dos sotaques da terra. Casa e corpo são extensões dos desejos que ali se alicerçaram. Em ambos as projeções do existir. Neles se guardam as lembranças, álbuns da existência. Paredes, carne, fotografias e cartas registrando o pertencimento a uma família, os afagos do amor, o conhecimento de si, uma voz de dentro exalando o desejo de viver.

Mariano, o personagem principal, volta para casa do avô e descobre mais do que sua árvore genealógica; desvela sensações, percorre a casa e tudo o que o liga àquela terra, àquela família na ilha de Luar-do-Chão. Perscruta as guerras tanto externas quanto internas. Tendo partido sabia: "Quem parte de um lugar tão pequeno, mesmo que volte, nunca retorna.” (COUTO, 2003, p. 45). Essas tinham sido as palavras do avô, alertando-o de que a casa não o reconheceria quando voltasse.

A casa é comparada a um ventre a que ele retorna e em que pode visitar os territórios da infância,

7 Em um excerto de um diálogo entre o italiano e Deusqueira em O Último Voo do Flamingo, ele diz:

"Tenho saudades de minha casa, lá na Itália.

- Também eu gostava de ter um lugarzinho meu, onde pudesse chegar e me aconchegar.

- Não tem, Ana?

- Não tenho? Não temos, todas nós, as mulheres.

- Como não?

- Vocês, homens, vêm para casa. Nós somos a casa.” (COUTO, 2005, p. 79). 
através das cartas para o avô já morto, ou ainda estaria vivo na casa? Mariano busca as caligrafias de existência. Por que teria voltado? O que o vincula à terra? Que rios percorrem sua existência e o levam para longe? Que águas o trazem de volta? Ele diz: "Avisto a nossa casa grande, a maior de toda a ilha. Chamamos-lhe Nyumba-Kaya, para satisfazer familiares do Norte e do Sul. "Nyumba" é a palavra para nomear "casa" nas ilhas nortenhas. Nos idiomas do Sul se diz "Kaya." (COUTO, 2003, p. 28). A casa e o tempo prendem e podem libertar Mariano, resta saber se ele escapará dos segredos e lembranças familiares e terá força para recriar-se a si mesmo. "Não era apenas a casa que nos distinguia em Luar-do-Chão. A nossa cozinha nos diferenciava dos outros. Em toda a Ilha, as cozinhas ficam fora, no meio dos quintais, separadas da restante casa. Nós vivíamos ao modo europeu, cozinhando dentro, comendo fechados." (COUTO, 2003, p. 145).

Até mesmo o túmulo do chefe da família se chama casa: Yindlhu, pois se plantam os mortos, pois são eles coisa viva. O túmulo e a moradia têm o mesmo nome. Através do corpo, físico e metafórico, como a casa, os álbuns de família e as cartas com o avô já morto, a biografia de Mariano se entrelaça com os cômodos daquela casa e os vínculos com sua família. O que ele herda se entrelaça com a casa da infância, com os conflitos com o pai. Que objetos, rastros e restos mediam nossas relações? Em Mariano, os álbuns, as cartas e, por sua vez, as memórias, falam à sua existência sobre o seu próprio corpo e existência, sobre o tempo que passou e seus desejos de ontem e do presente. Reunir rastros e restos que sobram da vida e da história não é só uma forma de protesto, mas a tarefa silenciosa daquele que é narrador (GAGNEBIN, 2006).

Nosso corpo é, assim, mais amplo, pois nós, como pessoas, nos compomos também nas extensões desses artefatos. São escalas que vinculam nossas singularidades aos nossos processos coletivos, biografam as marcas de nossos passos, desvelam nossas genealogias. A pessoa é um todo, também quando consideramos seus artefatos: casas, vestígios, lembranças. Como afirma Strathern:

As pessoas compreendem que um objeto pode tanto ser um item específico quanto conter o mundo em si; ele condensa ou miniaturiza um contexto mais amplo. Assim, um objeto pode presentificar poderes ou forças que afetam a vida de uma pessoa, sejam eles imaginados como o ambiente, o somos ou a comunidade. [...] A casa das pessoas permanece um monumento singular a seus esforços agora invisíveis e é, de fato, 'considerada uma extensão de seu corpo e de sua pessoa. A construção de casas, um processo específico, encena a capacidade mais ampla que as pessoas têm de estenderem a si mesmas. $\mathrm{O}$ artefato específico - a construção- rememora isso. (STRATHERN, 2014, p. 495; 500).

Os vínculos a esses artefatos nos falam também às pessoas às quais nos vinculamos no contexto familiar. Em Mia Couto é muito presente essa relação que nós temos com o meio e como somos pessoas como um todo nas relações que tecemos e nos artefatos que nos rodeiam, como a casa, nossos álbuns de fotografias, nossos corpos, lembranças e sonhos. Em outro de seus livros, Venenos de Deus, remédios do diabo, vemos que até mesmo o choro, a expressão da dor, só pode ser feito longe de casa: "

Chorar faz-se longe de casa, onde ninguém escute nem veja: esse era o mandamento na família. A lágrima não pode tombar no soalho. Caso contrário, a pedra se torna carne e a casa pode sair voando, até não ser mais do que nevoeiro entre nevoeiro." (COUTO, 2008, p. 185).

"A casa é corpo" (COUTO, 2003, p. 28-29), seu teto, quartos, corredores, falam dos vivos e dos mortos. O corpo do morto se demora a deixar a casa com dificuldade de transitar as fronteiras do mundo. Mariano, o neto, só encontra a casa quando desvela seu próprio corpo e conhece a casa e de fato os que nela habitam. Em um tempo sem guerra e sem morte, a terra era como uma folha branca aberta ainda por ser escrita. A casa e o corpo parecem ser uma coisa só. O corpo sonâmbulo, amolecido pelo amor, parece o lar perfeito para abrigar e acolher. A casa reconquista raízes quando se desfazem as mentiras. A única porta que apenas uma chave ainda serve é a do "quarto de arrumos", 
nela tem seu corpo amado por rosto ausente. O chão duro da terra começa a se abrir. Antes "A terra negava abrir o seu ventre aos desígnios humanos." (COUTO, 2003, p. 187), não se podiam enterrar os cadáveres, a agricultura se paralisara, os trabalhos de construção, as minas, dragagens nos portos. Ninguém sabia explicar o grave desequilíbrio que se dava na terra. Nas cartas com o avô e nos sonhos, Mariano descobre os cheiros da terra, eles se assemelham com os cheiros da casa. O amor "reparara a terra?" (COUTO, 2003, p. 189). A casa, a terra e as relações se entrelaçam e encontramos isso no sentido em que vai ser dado à pobreza. Em Luar-do-Chão, não há palavra para dizer "pobre", diz-se "órfão". Essa é a verdadeira miséria, não ter parente. Não ter vínculos, não ter casa para onde voltar. Nas línguas de Moçambique, explica Mia Couto, não existe a palavra “pobre”, pois:

Um pobre é designado chisiwana, expressão que quer dizer órfão. Nessas culturas, o pobre não é apenas o que não tem bens, mas é sobretudo o que perdeu a rede de relações familiares, que, na sociedade rural, serve de apoio à sobrevivência. $\mathrm{O}$ indivíduo é pobre quando não tem parentes. A pobreza é a solidão, a ruptura com a família. (COUTO, 2011, p. 20).

O corpo amado é também como uma casa, um lugar, onde as recordações estão adormecidas, onde o afeto e a intimidade são despertados. Tanto Kindzu e Farida, como Mariano e Nyembeti se escutam e se aquecem. No amor se vinculam de novo à terra e aos seus encontros com as águas. "Os lugares não se encontram, constroem-se.” (COUTO, 2003, p. 189). Nas palavras de Ingold, uma casa:

é um lugar onde as linhas de seus residentes estão fortemente atadas. Mas estas linhas não estão contidas dentro da casa tanto quanto fios não estão contidos em um nó. Ao contrário, elas trilham para além dela, apenas para prenderem-se a outras linhas em outros lugares, como os fios em outros nós. (INGOLD, 2005, p. 220).

\section{Escritas da existência: cartas, cadernos, álbuns fotográficos e sonhos}

A escritura da vida vai se dando nas duas ficções para além das linhas escritas. As cartas são vozes. Os cadernos desenham o destino, os álbuns fotográficos são manuseados com a ponta dos dedos, pois se sabe que eles podem despertar os fotografados. Sofre-se de sonhos!

Em Terra Sonâmbula, Virgínia, a portuguesa, a quem Farida teve como mãe, vivia entre o amor, as interdições do marido e as saudades de sua terra. Farida a questiona sobre o porquê de não gostar da terra africana onde vive. Ela responde que quem disse que não gosta? Era por razão desse amor que ela queria partir, era por causa dos maus-tratos, que eram como um espinho a sangrar seus corações, que ela ansiava partir. Até o vestido verde estava sempre pronto e pendurado, sem nenhuma ruga para a sua viagem. Na janela ela desenhava com seu olhar uma "geografia de saudade". As saudades dos seus era abrandada porque ela retomava seus álbuns fotográficos:

Sobre velhas fotografias, com um lápis, a velha portuguesa desenhava outras imagens. Às vezes, recortava-as com uma tesourinha e colava as figuras de umas fotos nas outras. Era como se movesse o passado dentro do presente

- Olhas, vês? Este é o meu tio. Foi quando ele veio cá visitar-nos.

Um tal parente jamais estivera em África. Mas Farida nem ousava desmentir. As fotos recompostas traziam novas verdades a uma vida feita de mentiras. (COUTO, 2007, p. 75).

Nas montagens de Virgínia, ela remonta sua própria vida, conjugando o passado no presente. Mesmo em seu quarto, Farina encontra objetos que abrigam Virgínia de sua solidão, cabelos de Farina, "caracoladinhos como crianças no ventre materno" (COUTO, 2007, p. 77) e uma fotografia sua na parede, que ela pensa pegar para si, pois era sua única imagem, mas, ao retirar a fotografia, 
no papel amarelecido: "Ela já não estava mais sozinha. Em redor do rosto dela estavam desenhadas figurinhas várias, tantas que pareciam mover-se e trocarem de posição. Sorriu, decidida a devolver a moldura à parede. Aquela era obra de Virgínia, pondo vida em seu retrato." (COUTO, 2007, p. 78).

Ela monta seu mundo, com uma geografia narrativa própria. Ela manuseia quem pode entrar no seu presente e visitá-la e quem ficará esquecido no passado. Sua memória seleciona o que deseja recordar, quais espaços de Portugal podem fazer parte como colagens de seu mundo em África. Como lembra Samain:

As fotografias são tecidos, malhas de silêncio e de ruídos. Precisam de nós para que sejam desdobrados seus segredos. As fotografias são memórias, histórias escritas nelas, sobre elas, de dentro delas, com elas. É por essa razão, ainda, que as fotografias se acumulam como tesouros, dentro de pastas, de caixinhas, de armários, que elas se escondem dentro de uma carteira. Elas são nossos refúgios, os envelopes que guardam nossos segredos. As pequenas peles, as películas, de nossa existência. As fotografias são confidências, memórias, arquivos. (SAMAIN, 2012, p. 160).

As fotografias reavivam memórias são como "uma espécie de clarão na noite, um grito, um apelo" (SAMAIN, 2012, p. 161). Convocam seres existentes em tempos passados, vivos e mortos, evocam narrativas, são arquivos que nos põem diante de nossa própria história. São "vestígios do real", mas não apenas objeto de observação, mas sujeitos da aparição." (ASSMANN, 2011, p. 245).

Além das fotos, Virgínia também pede que Farina a escreva cartas, falseando autorias, como se fosse um parente distante. Quando as cartas chegam em suas mãos, sempre de um diferente familiar inventado, ela lê as cartas entre soluços e choro, sem se importar com a irrealidade do escrito. Não sabemos pelo texto quem Virginia escolhe para que Farina represente a autoria, mas, mesmo sem saber, sabemos que ela seleciona camadas de seu passado, reinventa paisagens para ele, torna-o vivo, numa linguagem que somente ela escuta e compreende. Tanto as cartas quanto as fotos são como "cascas", camadas da vida de Virgínia, nas quais ela se reinventa. Diante delas, ela monta paisagens com tempos heterogêneos, letras e imagens que constroem uma narrativa visual para contar histórias para si mesma para continuar a existir.

Em Terra Sonâmbula, o livro é montado com as peregrinações de Muidinga e o velho Tuahir e as anotações de Kindzu, que, mesmo já morto, escreve com letras vivas as agruras da guerra, as tristezas das paisagens e dos sonhos que perpassam sua alma. De suas palavras sabemos do seu amor por Farida e de como ela própria parecia ser mulher e ao mesmo tempo água e claridade. Mas é também corpo que se confunde com uma caverna aquecida. Muidinga atravessa as imagens de um tempo que não pode tocar. Tudo é lento, os passos, a leitura, até mesmo o autocarro é apenas resto apodrecendo, o que sobra de Kindzu, do que há de humano naquela terra. $\mathrm{O}$ escritor, também sonâmbulo pelos cenários por onde seus personagens caminham ou também escrevem, mostra-nos um mundo devastado, mas permeado de sonhos. "Os sonhos são cartas que enviamos a nossas outras restantes vidas, compreende Muidinga. "Os cadernos de Kindzu não deveriam ter sido escritos por mão de carne e ossuda mas por sonhos iguais aos dele." (COUTO, 2007, p. 65). A caligrafia de Kindzu contém letras que se convertem em grãos de areia, seus escritos são como "páginas da terra" (COUTO, 2007, p. 204).

Na viagem de Terra Sonâmbula, pela caminhada e pela leitura se sonha encontrar pela estrada o caminho de casa, ou o reencontro propriamente dito com uma Moçambique onde seja possível uma costura da sua história. A partir das ruínas, reencontrar o rio que limparia a terra acariciaria suas feridas. O rio é como um sonho, ele faz a "costura dos destinos dos viventes". (COUTO, 2007, p. 87). Todos caminham, Kindzu, Mariano, Muidinga, os velhos Tuahir e Mariano. Tocam a terra com seus pés, sentem com seus corpos, transformam-se nela, pois dela é que o grão se transforma em alimento, é onde os cadáveres se metamorfoseiam em espíritos. A terra é o que cobre (RATTES, 2014). Vaga-se 
com os mortos, conversa-se com eles. É todo um espaço social que se dá numa interação entre vivos e mortos.

Mariano volta a casa e cumpre os ciclos das visitas: a casa, a terra, o homem e o rio, "o mesmo ser, só diferindo de nome." (COUTO, 2003, p. 258). Desde que chega, começa a receber secretas correspondências do avô. Essas cartas desvelam grafias em seus dedos do avô que estreia como pai, fazendo com que ele seja outro. "Estas cartas Mariano não são escritos. São falas. É por isso que você visitará estas cartas e encontrará não a folha escrita mas um vazio que você mesmo irá preencher; com suas caligrafias" (COUTO, 2003, p. 65). As cartas dão vozes, Mariano dá as escrituras, é isso o que o avô lhe diz. Não teria sido pela morte do avô que Mariano teria voltado; cruzou as águas ou o tempo, por motivo de um nascimento: o dele próprio. "[...] não veio salvar o morto. Veio salvar a vida, a nossa vida." (COUTO, 2003, p. 64). Não é nos livros e nem em seus cadernos, escondidos pelo pai, que Mariano descobre a si mesmo, mas nas tortuosas linhas do seu avô falecido, e quando ele próprio se sente inteiramente daquela terra. "Caligrafia não é hereditária como o sangue?" (COUTO, 2003, p. 56).

As fotografias em Um rio chamado tempo aparecem quando Mariano toma conhecimento sobre a morte do avô. Ele teria morrido quando a família se alinhava para posar para uma fotografia, quando as máquinas dispararam os flashes. "O velho Mariano, alegre, ditava ordens, distribuía uns e outros pelos devidos lugares, corrigia sorrisos, arrumava alturas e idades". De repente seu sorriso permaneceu congelado e seu rosto fixo. "[...] coração se suspendera em definitivo retrato.” (COUTO, 2003, p. 57). Depois, quando Mariano já está em casa sentado com a avó Dulcineusa, ele escuta as suas memórias sobre o avô. A avó busca ainda saber se no casamento o avô teve sentimentos por ela. "Enviuvar" para ela parece um casamento. Contando como os dois se conheceram, ela pede a Mariano que ele pegue um álbum de fotografias. Afaga uma mão na outra, como se para "rectificar o seu destino". Ela:

Aponta um velho álbum de fotografias pousado na poeira do armário. Era ali que, às escondidas, ela vinha tirar vingança do tempo. Naquele livro a avó visitava lembranças, doces revivências. Mas quando o álbum se abre em seu colo eu reparo, espantado, que não há fotografia nenhuma. As páginas de desbotada cartolina estão vazias. Ainda se notam as marcas onde, antes, estiveram coladas fotos.

- Vá sente aqui que eu lhe mostro.

Finjo que acompanho, cúmplice da mentira.

- Estás a ver aqui seu pai, tão novo, tão clarinho até parece mulato?

E vai repassando as folhas vazias, com aqueles seus dedos sem aptidão, a voz num fio como se não quisessem despertar os fotografados. (COUTO, 2003, p. 50).

Mesmo naquele mundo fantasioso. Mariano não tem coragem de desmentir a avó. Ele mesmo deixa seus olhos serem conduzidos pelas imagens que somente ela vê, a ponto de querer que seus dedos se entrelacem naquelas imagens e ganhem formas e real existência:

- Aqui, veja bem, aqui está sua mãe. E olhe nesta, você tão pequeninho! Vê como está bonita consigo no colo?

Me comovo, tal é a convicção que deitava em suas visões, a ponto de os meus dedos serem chamados a tocar o velho álbum. Mas Dulcineusa corrige-me.

- Não passe a mão pelas fotos que se estragam. Elas são o contrário de nós: apagam-se quando recebem carícias. (COUTO, 2003, p. 50).

Mariano se deixa vencer pelos devaneios de Dulcineusa. Empurra a ilusão para mais longe, deixando com que aquelas imagens tornem a realidade, talvez menos dura, e de algum modo, adocem o coração da avó, na dor das suas ausências e naquilo que ela não encontra nem mesmo na memória.

Dulcineusa queixa-se que ela nunca aparece em nenhuma foto. Sem remorso, empurro mais longe a ilusão. Afinal, a fotografia é sempre uma mentira. Tudo na vida está acontecendo 
por repetida vez.

- Engano seu. Veja esta foto, aqui está a avó.

- Onde ? Aqui no meio desta gente toda?

- Sim, Avó. É a senhora aqui de vestido branco.

- era uma festa? Parece uma festa.

- era a festa de aniversário da avó!

Vou ganhando coragem, quase acreditando naquela falsidade.

- não me lembro que me tivessem feito uma festa...

- E aqui, veja aqui, é o avô lhe entregando uma prenda.

- Mostre! Que prenda é essa, afinal?

- É um anel, Avó. Veja bem, que brilha esse anel!

Dulcineusa fixa a inexistente foto de ângulos diversos. Depois, contempla longamente as mãos como se as comparasse com a imagem ou nelas se lembrasse de um outro tempo. (COUTO, 2003, p. 50).

Ao final do livro, quando Mariano se reencontra com a casa, ele compreende seus vínculos com a terra e com as pessoas que são as suas raízes em Nyumba-Kaya. O Mariano avô entra definitivamente em sua morte, fazendo com que a terra volte a se abrir às mãos humanas. Mais uma vez, ele se encontra com a avó na cozinha. Este parece ser sempre o lugar dos cozimentos, no qual, no tempo das fervuras, os fios dos segredos e dos entendimentos se encontram com os cheiros dos temperos e das comidas. Não só os alimentos, mas, ali, até mesmo os sofrimentos se cozinham. "O segredo é demorar o sofrimento, cozinhá-lo em lentíssimo fogo, até que ele se espalhe, diluto, no infinito do tempo." (COUTO, 2003, p. 48). Nela, a avó Dulcineusa prepara a refeição enquanto recita uma "reza invariavelmente repetida." (COUTO, 2003, p. 95). Na cozinha os sussurros e silêncios são linguagens próprias, o tempo do preparo das comidas é o tempo da vida. Fogo que ascende e ensina asas.

A cozinha me transporta para distantes doçuras. Como se, no embaciado dos vapores, se fabricasse não o alimento, mas o próprio tempo. Foi naquele chão que inventei brinquedo e rabisquei os meus primeiros desenhos. Ali escutei falas e risos, ondulações de vestidos. Naquele lugar recebi os temperos do meu crescer. (COUTO, 2003, p. 145).

Dessa vez, a avó está com a tia Admirança, contemplando o álbum de família e chama Mariano para ver. “Toda família cabe em retrato?", para ele não. As famílias africanas se estendem como túneis de formigueiro.” Não cabem dentro de um retrato, pois o tempo da imagem não é o tempo da história. Ao Mariano chegar, a história de sua família e dele mesmo parecia suspensa, nem mesmo os álbuns tinham imagens, apenas a imaginação da avó. Seguindo o tempo dos rios, ${ }^{8}$ encontrando os lugares mais subterrâneos de sua terra, agora:

O álbum está cheio de fotografias. E lá está o velho Mariano, lá está Dulcineusa recebendo prendas. E no meio de tudo, entre as tantíssimas imagens, consta uma fotografia minha nos braços de Admirança.

- Olha nós dois, Mariano.

Levanta o branco para me dar a mão. Quero falar mas reparo que não consigo chamá-la de "mãe". Abraço-a como se fora agora que eu chegasse a casa. (...)A casa tinha reconquistado raízes. Fazia sentido, agora, aliviá-las das securas. (COUTO, 2003, p. 246-247).

Nas duas experiências literárias de Mia Couto, a escrita se desdobra para ouvir os movimentos da cultura moçambicana, mas, ciente dos limites da letra, o escritor percorre a força da imagem, das lembranças e dos sonhos, toma-as como caligrafias que acalmam e dão lugar aos corpos. Alimentam os alicerces da casa, pois desfiam as memórias dos lugares. O corpo é um meio onde as recordações se ancoram. Os lugares tornam possível o retorno e a preservação, mesmo que sejam de ruínas, para

8 Cf. Samain (2012) O tempo das imagens é como o tempo dos rios e das nuvens, como eles, elas correm, murmuram e se calam, podem simplesmente deixar de existir. 
que delas se reconstituam, entre vestígios, os sentidos à vida. As vidas não são vividas dentro dos lugares, mas "através, em torno, para e de lugares", para lembrar Ingold (2005, p. 220). A existência humana é "situante", formada por trilhas, peregrinações. Como poderia apenas a escrita dar conta de acompanhar esses caminhos? Narrar é antes perceber que, para contar uma história, é preciso se acercar de inúmeros fios ou letras. Os lugares são atados com os novelos de palavras, elas, por sua vez, são tão soltas e diversas quanto as experiências que por eles passam. ${ }^{9}$

\footnotetext{
9 Uma inspiração para pensar sobre isso pode ser encontrada no filme How to Make an American Quilt, traduzido em português para: Uma colcha de retalhos de 1995, sob a direção de Jocelyn Moorhouse. As grafias da vida são muitas. Grafar é escrever, traçar. No filme através da máquina de escrever, dos bordados das mulheres ou do mural de "mágoas", feitos com pedaços de coisas quebradas, percebemos como as lembranças podem ser grafadas por diversas caligrafias. Apesar de suas singularidades, como narrativas, lembram-nos que sempre é importante saber escolher bem os retalhos ou as palavras.
} 


\section{Referências}

ASSMANN, Aleida. Espaços da recordação. Formas de transformação da memória cultural. Campinas, SP: Editora da Unicamp, 2011.

BARTHES, Roland. Aula. São Paulo: Cultrix, 1977. p. 7-47.

CERTEAU, Michel de. A Invenção do Cotidiano: 1. Artes de Fazer. Petrópolis, RJ: Vozes, 2009.

CERTEAU, Michel de. Os sistemas de sentido: o escrito e o oral. In: A escrita da história. 3. ed. Rio de Janeiro: Forense, 2011.

COUTO, Mia. Terra sonâmbula. São Paulo: Companhia das Letras, 2007.

COUTO, Mia. Um rio chamado tempo, uma casa chamada terra. São Paulo: Companhia das Letras, 2003.

COUTO, Mia. Poemas escolhidos. $1^{\text {a }}$ ed. São Paulo: Companhia das Letras, 2016.

COUTO, Mia. Venenos de Deus, remédios do diabo: as incuráveis vidas de Vila Cacimba. São Paulo: Companhia das Letras, 2008.

COUTO, Mia. O último voo do flamingo. São Paulo: Companhia das Letras, 2005.

COUTO, Mia. Língua que não sabemos que sabíamos; Luso-afonias - a lusofonia entre viagens e crimes. In: E se Obama fosse africano?: e outras intervenções. $1^{a}$ ed. São Paulo: Companhia das Letras, 2011.

COUTO, Mia. Onze perguntas para Mia Couto, uma entrevista inspiradora. $1^{\circ}$ set. 2011. Disponível em: $\quad<$ http://www.buala.org/pt/cara-a-cara/onze-perguntas-para-mia-couto-uma-entrevistainspiradora $>$. Acesso: $1^{\mathrm{o}}$ set. 2011.

COUTO, Mia. Entretien par Marine Landrot: Mia Couto veut "respecter l'oralité, tout en la recréant pour en faire de la littérature. Publié le 06/07/2015. Disponível em: <http://www.telerama.fr/livre/ mia-couto-veut-respecter-l-oralite-tout-en-la-recreant-pour-en-faire-de-la-litterature, 128866.php $>$. Acesso: 14 fev.2017.

COUTO, Mia. Café Filosófico especial com Mia Couto. 26 jun. 2017, 19h. Fronteiras do Pensamento. Iguatemi Shopping Campinas. Transmissão online - CPFL.

GAGNEBIN, Jeanne Marie. Lembrar Escrever Esquecer. São Paulo: Ed. 34, 2006.

INGOLD, Tim. Estar vivo: ensaios sobre movimento, conhecimento e descrição. Petrópolis-RJ: Vozes, 2015.

MANGUEL, Alberto. Uma história da leitura. São Paulo: Companhia das Letras, 1997.

STRATHERN, Marilyn. A pessoa como um todo e seus artefatos. In: O efeito etnográfico e outros ensaios. São Paulo: Cosac Naify, 2014.

SAMAIN, Etienne. As peles da fotografia: fenômeno, memória/arquivo, desejo - DOI 10.5216/vis. v10i1.23089. Visualidades, v. 10, n. 1, jan./jun. 2012. ISSN 2317-6784. Disponível em: <http:// revistas.ufg.emnuvens.com.br/VISUAL/article/view/23089>. Acesso em: 16 abr. 2016. doi:http:// dx.doi.org/10.5216/vis.v10i1.23089

RATTES, Kleyton. A Moçambique pasmada. Um lugar batizado de antigamente. Emblemas. Revista do Departamento de História e Ciências Sociais - UFG/CAC, v. 11, n. 1, 39-86, jan./jun., 2014. 
